\title{
EVALUATION OF ABSORBED DOSE DISTRIBUTION IN MELANOMA B16F10 DURING CONTRAST ENHANCED RADIOTHERAPY WITH INTRATUMORAL ADMINISTRATION OF DOSE-ENHANCING AGENT
}

Lipengolts $A A^{1,2,3} \otimes$, Vorobyeva $E S^{2}$, Cherepanov $A A^{1}$, Abakumov $\mathrm{MA}^{4,5}$, Abakumova $\mathrm{TO}^{6}$, Smirnova $\mathrm{AV}^{1,7}$, Finogenova $\mathrm{YuA}^{4}$, Grigorieva EYu ${ }^{1,3}$, Sheino IN², Kulakov VN²

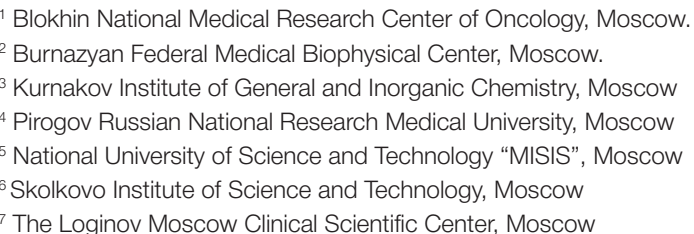

Contrast-enhanced radiotherapy (CERT) is a binary treatment modality in which the absorbed radiation dose is not only determined by the parameters of the external radiation source but also affected by the concentration of a dose-enhancing agent (DEA) in the studied object. In this work we assessed the distribution of the absorbed dose in a murine B16F10 melanoma injected with a single dose of an aqueous Bi-DTPA solution. The mice were exposed to a single fraction of X-ray irradiation for 28.5 min. In vivo measurements of DEA concentrations were done on a micro-CT scanner using the radiopacity values of malignant tissues from the obtained CT images. We found that the presence of DEA enhanced the absorbed dose more than twofold in $6 \%$ of the tumor volume; in $29 \%$ of the tumor volume the absorbed dose increased more than onefold. The tumor growth delay time calculated for our model was 0.76 days (we only accounted for the damage caused directly by radiation), whereas in our previous research study tumor growth delay was 10 days. This discrepancy may indicate that in the tumors exposed to contrast-enhanced radiotherapy growth delay results from both the damage directly caused by radiation and other antitumor mechanisms.

Keywords: radiotherapy, contrast enhanced radiotherapy, melanoma B16F10, dose enhancement, CT, dose-volume histogram Funding: the study was supported by the Russian Science Foundation (Project ID 18-13-00459).

$\triangle$ Correspondence should be addressed: Alexey A. Lipengolts

Kashirskoe shosse 24, Moscow, 115478; lipengolts@mail.ru

Received: 28.09.2018 Accepted: 20.10.2018

DOI: $10.24075 /$ brsmu.2018.062

\section{ИССЛЕДОВАНИЕ РАСПРЕДЕЛЕНИЯ ПОГЛОЩЕННОЙ ДОЗЫ ПРИ ФОТОН-ЗАХВАТНОЙ ТЕРАПИИ С ИНТРАТУМОРАЛЬНЫМ ВВЕДЕНИЕМ ДОЗОПОВЫШАЮЩЕГО АГЕНТА В МЕЛАНОМЕ В16F10}

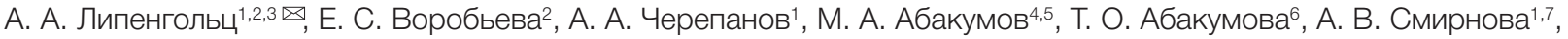

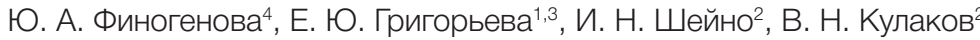

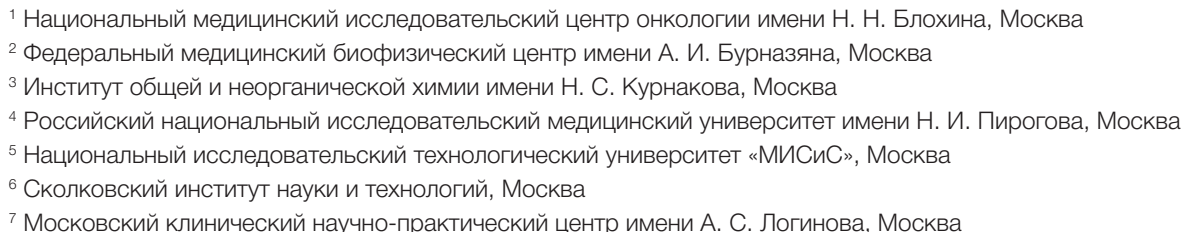

Московский клинический научно-практический центр имени А.С.Логинова, Москва

\begin{abstract}
В фотон-захватной терапии (ФЗТ) величина поглощенной дозы определяется не только параметрами облучения, но и концентрацией дозоповышающего агента (ДПА) в облучаемом объекте. В данной работе было проведено расчетноэкспериментальное исследование распределения поглощенной дозы на опухолевой модели мышиной меланомы B16F10, после однократной интратуморальной инъекции висмута в качестве ДПА в форме водного раствора комплекса Ві-ДТПА. Оценку поглощенной дозы проводили для однофракционного рентгеновского облучения длительностью 28,5 мин. Количественное определение ДПА in vivo осуществляли при помощи микро-КТ, используя значения рентгеноплотности опухолевых тканей на полученных КТ-томограммах. В результате исследования установлено, что за счет присутствия ДПА в 6\% объема опухоли поглощенная доза увеличивалась более чем в 2 раза и в $29 \%$ объема опухоли наблюдалось увеличение поглощенной дозы, отличное от 1. Время задержки роста опухоли, рассчитанное для полученного дозо-объемного распределения с учетом только непосредственного радиационного поражения опухолевых клеток, составило 0,76 суток, тогда как в ранее проведенных экспериментальных исследованиях данная величина равнялась 10 суткам. Полученное несоответствие может указывать на то, что торможение роста опухоли при ФЗТ с интратуморальным введением ДПА достигается за счет не только непосредственного радиационного поражения опухоли, но и иных противоопухолевых механизмов.
\end{abstract}

Ключевые слова: лучевая терапия, фотон-захватная терапия, меланома B16F10, увеличение дозы, КT, дозообъемное распределение

Финансирование: исследование выполнено при финансовой поддержке гранта РНФ 18-13-00459.

Для корреспонденции: Алексей Андреевич Липенгольц

Каширское ш., д. 24, г. Москва, 115478; lipengolts@mail.ru

Статья получена: 28.09.2018 Статья принята к печати: 20.10.2018

DOI: 10.24075/vrgmu.2018.062 
Fighting cancer is one of the top public health priorities. Radiotherapy is an effective treatment modality used in patients with different malignancies. However, its efficacy against some radioresistant tumors remains as low as $30-50 \%$ [1]. It can be improved by increasing the absorbed radiation dose at the cost of damage to healthy surrounding tissues. One of the methods of increasing the absorbed dose while sparing healthy tissues is contrast-enhanced radiotherapy (CERT), in which dose enhancement is achieved by injecting or otherwise delivering dose-enhancing agents (DEA) to the tumor. DEA are chemical elements with high $Z$ numbers $>52$, such as I, Gd, $\mathrm{Au}, \mathrm{Pt}, \mathrm{Bi}$, etc. These elements readily absorb external X-rays and therefore can be used to enhance the dose absorbed by the tumor at the site of their uptake [2-4]. Unlike conventional radiotherapy in which tumor geometry is important, CERT precision is ensured by the tumor-tropic properties of DEAbased pharmaceuticals. The antitumor effect of CERT has been demonstrated in a number of research studies conducted in animals [5-11]. Unfortunately, the obtained results cannot be translated into clinical practice, because a treatment outcome cannot be predicted without establishing a correlation between the observed therapeutic effect and the absorbed radiation dose/its distribution in the tumor.

The hardest part of both research and clinical studies of CERT efficacy is dosimetry, which is also its least elaborated component. CERT is a binary modality; the absorbed dose and its distribution in the tumor volume are determined not only by the parameters of external radiation, but also by DEA concentration and distribution in the tumor volume.

The intratumoral route of DEA administration is used in the studies of CERT tumor suppressing efficacy both in lab animals [12-17] and in real patients in the clinical setting [18].

The aim of this work was to study the distribution of bismuth during CERT in the volume of a tumor grown from B16F10 murine melanoma cells following the intratumoral administration of its single dose and to analyze the dose-volume histogram data.

\section{METHODS}

The study was conducted in C57BI/6 female mice weighing 20 to $22 \mathrm{~g}$ purchased from Stolbovaya breeding and nursery laboratory (Research Center for Biomedical Technologies of FMBA; Russia). The animals were housed in a conventional facility under natural lighting conditions. Murine melanoma B16F10 was used as a tumor model. The 14\% cell suspension in $0.2 \mathrm{ml}$ Hanks balanced salts prepared ex tempore was injected subcutaneously in the middle third of the right hind leg. DEA distribution was measured in the tumors of 6 animals once the malignancies reached $\sim 700 \mathrm{~mm}^{3}$ in size. Tumor dimensions were measured with a caliper in three perpendicular planes and the tumor volume was calculated using the ellipsoid volume formula.

Bismuth diethylenetriaminepentaacetic acid (Bi-DTPA) used in our previous research study of CERT efficacy was chosen as DEA [15]. Properties of the Bi-DTPA aqueous solution are shown in the Table.

The animals received a single bolus intratumoral injection of $50 \mu \mathrm{l}$ of the Bi-DTPA solution containing $5 \mathrm{mg}$ of bismuth.

Distribution of DEA in the tumor volume in vivo was studied by micro-CT [19-21] performed on the IVIS Spectrum CT scanner (Perkin Elmer; USA). For the procedure, the mice were anesthetized with $2 \%$ isoflurane in air. The whole body scans were obtained before the injection, $\sim 1 \mathrm{~min}$ after the injection, and then $3,5,10,15,20,25$, and 30 min following the injection. Examples of CT tumor images obtained before and after intratumoral DEA administration are shown in Fig. 1. Once the scanning was completed, the anesthetized mice were euthanized by cervical dislocation.

DEA concentrations in the tumors were calculated from the radiopacity per each pixel of the tomographic image. Because the absolute radiopacity values for the homogenous object returned by the IVIS Spectrum CT scanner depend on the tomographic slice number and differ significantly between in the central and peripheral zones of a studied object [22], we calculated DEA concentrations from the difference between the radiopacity of tumor tissues measured before and after the DEA injection. Calibration curves were constructed from the scans of reference tubes containing solutions with known bismuth concentrations (Fig. 2).

To estimate the absorbed radiation dose per pixel on the CT image of the tumor, the dose enhancement factor (DEF) was calculated for the corresponding DEA concentration in this particular pixel measured in every studied time interval. DEF is a ratio of the dose absorbed by an object in the presence of DEA to the dose absorbed in the absence of DEA, irradiation parameters being the same. DEF is calculated by the formula:

$$
\mathrm{DEF}=D_{\mathrm{DEA}}(C) / D_{0}
$$

where $D_{D E A}(C)$ is the absorbed dose at a point in an object containing the DEA concertation $C$ irradiated with $/$ intensity at this particular point; $D_{0}$ is the absorbed dose at the same point in the same object with zero DEA concentration $(C=0)$ upon irradiation with the same intensity $I_{0}$ [23].

DEF was calculated from measured DEA concentrations based on experimental and theoretical data [2, 24]. DEF values were time-averaged in the 0-30 min interval; the same irradiation time was used in our previous work [15]. Then tumor voxels with the same average DEF values were added up to obtain dose-volume histograms. Because the presence Table. The main physical and chemical properties of the Bi-DTPA solution

\begin{tabular}{|l|c|}
\hline \multicolumn{1}{|c|}{ Parameter } & Value \\
\hline Gross formula & $\mathrm{BiNa}_{2} \mathrm{C}_{14} \mathrm{H}_{18} \mathrm{O}_{10} \mathrm{~N}_{3}$ \\
\hline Molecular weight, Da & 643.253 \\
\hline Metal content, wt $\%$ & 34 \\
\hline Molarity M & 0.5 \\
\hline Solution $\mathrm{pH}$ & 7.4 \\
\hline Density at $20^{\circ} \mathrm{C}, \mathrm{g} / \mathrm{cm}^{3}$ & 1.19 \\
\hline Complex stability, logK & 31 \\
\hline
\end{tabular}

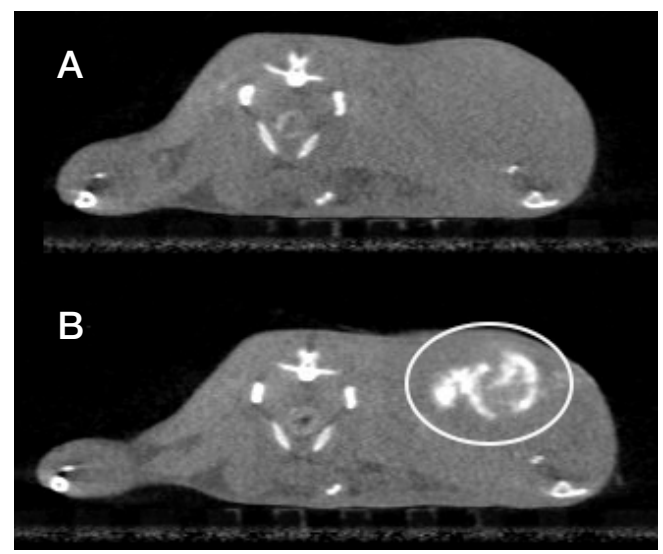

Fig. 1. The CT scans of a mouse with melanoma B16F10 before (A) and after (B) the intratumoral injection of $50 \mu \mathrm{L}$ of the Bi-DTPA solution containing bismuth at a concentration of $104.5 \mathrm{mg} / \mathrm{mL}$ 
of DEA leads to a local increase of the absorbed dose (the tumor or its part receives a radiation dose exceeding the one expected in the absence of DEA), we used modified cumulative dose-volume histograms different from those constructed for a conventional radiotherapy. The histograms demonstrate the dependency of DEF on the relative tumor volume expressed as percentages. In our study, each relative tumor volume was plotted against the minimal corresponding DEF. This type of dose-volume histograms is more informative for CERT because it visually represents the role of DEA in enhancing the radiation dose absorbed by the organ. The analysis of CT images, DEF computation and construction of dose-volume histograms were done in MATLAB (MathWorks; USA).

\section{RESULTS}

The analysis of Bi-DTPA distribution in the tumor injected with a single dose of DEA revealed that the half-life of Bi-DTPA in the tumor was 3 min. By minute 30 the tumor retained only $4 \%$ of the injected bismuth (Fig. 3).

The volume of Bi-DTPA distribution measured 1 min after the injection was $219 \pm 35 \mathrm{~mm}^{3}(24 \pm 1 \%$ relative to the total tumor volume) (Fig. 4).

During the first two minutes after the injection there was a competition between Bi-DTPA distribution in tumor tissues and its elimination from the tumor, which kept the DEA-containing

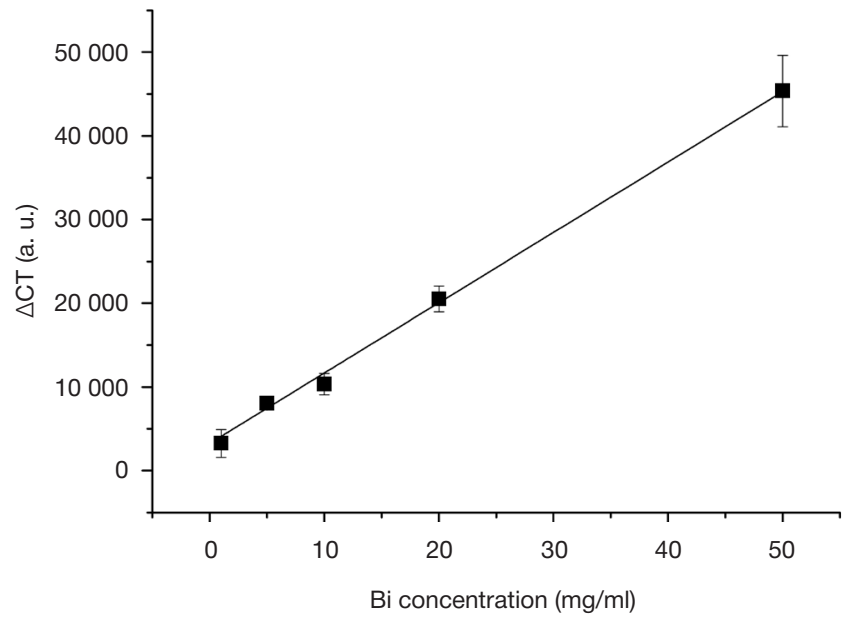

Fig. 2. The calibration curve showing the changes in radiopacity $(\triangle \mathrm{CT})$ detected on CT images produced by the micro-CT scanner IVIS Spectrum CT plotted against bismuth concentrations

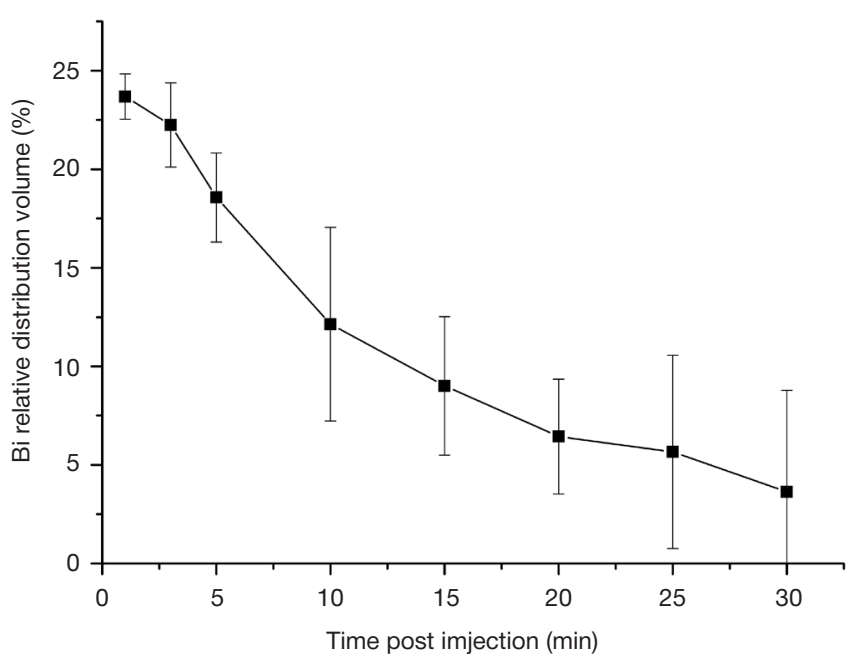

Fig. 4. The kinetics of DEA relative distribution volume in the tumor plotted against time elapsed after the injection tumor volume unchanged. Then it started to decline gradually and by min 25 following the injection was as low as $1-7 \%$ of the total tumor volume. The modified dose-volume histograms are shown in Fig. 5.

As shown by the histograms, a twofold increase in the absorbed radiation dose was observed for $6 \%$ of the total tumor volume. Additional energy release exceeding the nominal radiation dose $(\mathrm{DEF}>1)$ due to the presence of DEA was observed in $29 \%$ of the total tumor volume.

\section{DISCUSSION}

The obtained dose-volume histograms (Fig. 5) reveal a markedly nonuniform distribution of DEA in the tumor volume. The maximal predicted DEF value at the site of the maximum DEA concentration irradiated for 28.5 minutes is 4 . This ensures an absorbed radiation dose of 80 Gy at the dose intensity of $0.7 \mathrm{~Gy} / \mathrm{min}$. However, such a significant increase in the absorbed dose was observed for only $0.1 \%$ of the tumor volume. A 1.5-fold or more dramatic increase in the absorbed dose (> 30 Gy at the same dose rate) caused by the presence of DEA was observed in $10 \%$ of the tumor volume.

In order to estimate the maximum growth delay for the irradiated tumor, the following assumptions were made:

1) the irradiated tumor grows exponentially, its doubling time being $T d$ [25];

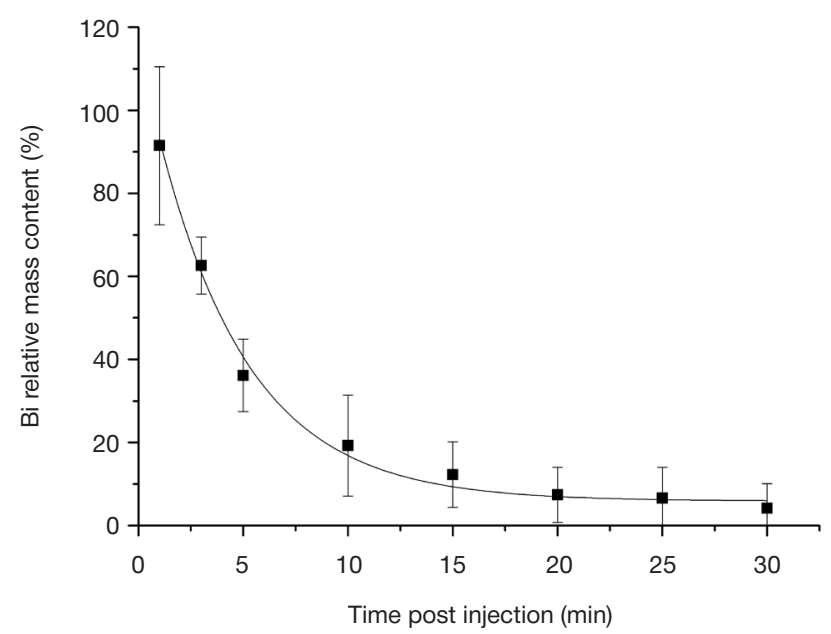

Fig. 3. The kinetics of bismuth relative mass content in the tumor plotted against time elapsed after the injection

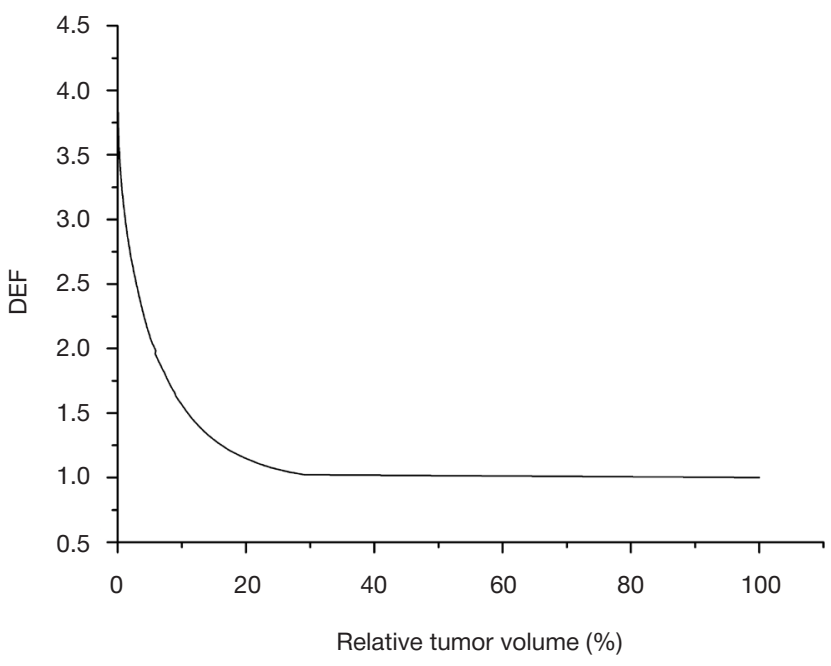

Fig. 5. The modified dose-volume histogram for B16F10 melanoma injected with DEA and subsequently exposed to X-rays for 28.5 minutes 
2) the death of tumor cells is caused only by direct damage induced by radiation;

3) total cell death is observed in that $10 \%$ of the tumor volume which was irradiated with a dose over 30 Gy.

The last assumption was made to simplify the estimation of the maximum growth delay time. If some cells in the irradiated volume do survive, the growth delay will be shorter, but the minimum growth delay time will not be affected. If the volume of the cells that survive irradiation in the absence of DEA is taken as $V_{s}$, then the volume of the cells surviving irradiation in the presence of DEA injected into the tumor will be $0.9 \mathrm{~V}$. If the doubling time is the same in both cases and equals 5 days [17, 26] and the tumor grows exponentially, then the growth delay time will not exceed 0.76 days in the tumor exposed to CERT.

However, our previous experiments [15] demonstrated a longer 10-day tumor growth delay in tumors injected with DEA and exposed to $\mathrm{X}$-ray radiation in comparison with those irradiated in the absence of DEA. Obviously, the antitumor effect observed in the B16F10 melanoma injected with DEA and subsequently exposed to a single fraction of $\mathrm{X}$-ray irradiation cannot be solely linked to the direct damage caused by radiation, but is supported by other mechanisms as well.

\section{CONCLUSIONS}

The analysis of DEA and absorbed dose distribution in the tumor volume revealed that a single intratumoral injection of DEA ensures its markedly nonuniform distribution in the tumor and enhances the absorbed radiation dose. To achieve a more uniform distribution of the dose-enhancing agent, multiple US/ CT-guided injections are needed. Our previous findings [15] highlight the importance of studying the mechanisms of CERT tumor suppression efficacy following DEA delivery to the tumor by the same route of administration.

\section{References}

1. Siegel RL, Miller KD, Jemal A. Cancer statistics, 2015. CA Cancer J Clin. 2015 Jan; 65 (1): 5-29.

2. Robar JL, Riccio S, Martin M. Tumour dose enhancement using modified megavoltage pho-ton beams and contrast media. Phys Med Biol. 2002 Jul 21; 47 (14): 305.

3. Kulakov VN, Lipengolts AA, Grigoreva EY, Shimanovskii NL. Pharmaceuticals for Binary Radiotherapy and Their Use for Treatment of Malignancies (A Review). Pharm Chem J. 2016 Sep 8; 50 (6): 19-25.

4. Roeske JC, Nunez L, Hoggarth M, Labay E, Weichselbaum RR. Characterization of the Theo-rectical Radiation Dose Enhancement from Nanoparticles. Technol Cancer Res Treat. 2007; 6 (5): 395-401.

5. Norman A, Ingram M, Skillen RG, Freshwater DB, Iwamoto KS, Solberg T. X-ray photother-apy for canine brain masses. Radiat Oncol Investig. 1997; 5 (1): 8-14.

6. Miladi I, Alric C, Dufort S, et al. The In Vivo Radiosensitizing Effect of Gold Nanoparticles Based MRI Contrast Agents. Small. 2014; 10 (6): 1116-24.

7. Le Duc G, Miladi I, Alric C, et al. Toward an Image-Guided Microbeam Radiation Therapy Using Gadolinium-Based Nanoparticles. ACS Nano. 2011; 5 (12): 9566-74.

8. Hainfeld JF, Dilmanian FA, Zhong Z, Slatkin DN, Kalef-Ezra JA, Smilowitz HM. Gold nano-particles enhance the radiation therapy of a murine squamous cell carcinoma. Phys Med Biol. 2010; 55 (11): 3045-59.

9. Hainfeld JF, Slatkin DN, Smilowitz HM. The use of gold nanoparticles to enhance radiothera-py in mice. Phys Med Biol. 2004; 49 (18): 309-15.

10. Hainfeld JF, Smilowitz HM, O'Connor MJ, Dilmanian FA, Slatkin DN. Gold nanoparticle imaging and radiotherapy of brain tumors in mice. Nanomedicine. 2013; 8 (10): 1601-09.

11. Dufort S, Le Duc G, Salomé M, et al. The High Radiosensitizing Efficiency of a Trace of Gadolinium-Based Nanoparticles in Tumors. Sci Rep. 2016; 6 (June): 1-8.

12. Komatsu T, Nakamura K, Okumura Y, Konishi K. Optimal method of gold nanoparticle ad-ministration in melanoma bearing mice. Exp Ther Med. 2018 Jan 12; 15 (3): 2994-9.

13. Rousseau J, Boudou C, Estève F, Elleaume H. ConvectionEnhanced Delivery of an lodine Tracer Into Rat Brain for Synchrotron Stereotactic Radiotherapy. Int J Radiat Oncol. 2007 Jul; 68 (3): 943-51.

14. Mello RS, Callisen H, Winter J, Kagan a R, Norman A. Radiation dose enhancement in tu-mors with iodine. Med Phys [Internet]. 1983 Jan; 10 (1): 75-8.

15. Lipengolts AA, Cherepanov AA, Kulakov VN, Grigoreva EY, Merkulova IB, Sheino IN. Comparison of the Antitumor Efficacy of Bismuth and Gadolinium as Dose-Enhancing Agents in Formulations for Photon Capture Therapy. Pharm Chem J. 2017 Dec 5; 51 (9): 783-6.
16. Cherepanov AA, Lipengolts AA, Nasonova TA, Dobrynina OA, Kulakov VN, Sheino IN et al. Increasing of antineoplastic effect of $\mathrm{x}$-ray irradiation in mice with transplanted melanoma B16F10 by use of gadolinium containing drug. Meditsinskaya fizika. 2014; (3): 66-9. (in Russian)

17. Maggiorella L, Barouch G, Devaux C, Pottier A, Deutsch E, Bourhis $\mathrm{J}$, et al. Nanoscale radio-therapy with hafnium oxide nanoparticles. Futur Oncol. 2012; 8 (9): 1167-81.

18. Bonvalot S, Le Pechoux C, De Baere T, Kantor G, Buy X, Stoeckle E, et al. First-in-Human Study Testing a New Radioenhancer Using Nanoparticles (NBTXR3) Activated by Radiation Therapy in Patients with Locally Advanced Soft Tissue Sarcomas. Clin Cancer Res. 2017 Feb 15; 23 (4): 908-17.

19. Hainfeld JF, O'Connor MJ, Dilmanian FA, Slatkin DN, Adams DJ, Smilowitz HM. Micro-CT enables microlocalisation and quantification of Her2-targeted gold nanoparticles within tu-mour regions. Br J Radiol. 2011; 84 (1002): 526-33. DOI:10.1259/ bjr/42612922.

20. Le Duc G, Corde S, Charvet A-M, Elleaume H, Farion R, Le Bas J-F, et al. In Vivo Meas-urement of Gadolinium Concentration in a Rat Glioma Model by Monochromatic Quantitative Computed Tomography. Invest Radiol. 2004 Jul; 39 (7): 385-93.

21. Lipengolts AA, Budaeva JA, Blaickner M, Cherepanov AA, Menkov MA, Kulakov VN, et al. lodine quantification with computed tomography for the purpose of dose assessment in contrast enhanced radiotherapy. Bull Russ State Med Univ. 2016; (6): 16-9.

22. Pervova W, Lipengolts AA, Cherepanov AA, Abakumov MA. Study of iodine, gadolinium and bismuth quantification possibility with micro-CT IVIS spectrumct in vivo imaging system. J Phys Conf Ser. 2017; 784 (1): 12043.

23. Vorobyeva ES, Lipengolts AA, Cherepanov AA, Grigorieva EY, Nechkina IN, Kalygina NS, et al. Feasibility of using 6 MV photon beams in contrast-enhanced radiotherapy. Bull Russ State Med Univ. 2017; (4): 57-61.

24. Cherepanov AA, Lipengolts AA, Vorobyeva ES, Kulakov VN, Klimanov VA, Grigorieva EYu. Experimental study of $x$-rays absorbed dose increase in medium containing high-Z element using Fricke dosimeter. Meditsinskaya fizika. 2016; 72 (4): 38-41. (in Russian)

25. Bristow RG, Hill RP. Comparison between in vitro radiosensitivity and in vivo radioresponse in murine tumor cell lines II: in vivo radioresponse following fractionated treatment and in vitro/in vivo correlations. Int J Radiat Oncol. 1990 Feb; 18 (2): 331-45.

26. Le UM, Kaurin DGL, Sloat BR, Yanasarn N, Cui Z. Localized irradiation of tumors prior to synthetic dsRNA therapy enhanced the resultant anti-tumor activity. Radiother Oncol. 2009 Feb; 90 (2): 273-9. 


\section{Литература}

1. Siegel RL, Miller KD, Jemal A. Cancer statistics, 2015. CA Cancer J Clin. 2015 Jan; 65 (1): 5-29.

2. Robar JL, Riccio S, Martin M. Tumour dose enhancement using modified megavoltage pho-ton beams and contrast media. Phys Med Biol. 2002 Jul 21; 47 (14): 305.

3. Кулаков В. Н., Липенгольц А. А., Григорьева Е. Ю., Шимановский Н. Л. Препараты для дистанционной бинарной лучевой терапии и их применение при злокачественных новооб-разованиях. Химико-фармацевтический журнал. 2016; 50 (6): 19-25.

4. Roeske JC, Nunez L, Hoggarth M, Labay E, Weichselbaum RR. Characterization of the Theo-rectical Radiation Dose Enhancement from Nanoparticles. Technol Cancer Res Treat. 2007; 6 (5): 395401.

5. Norman A, Ingram M, Skillen RG, Freshwater DB, Iwamoto KS, Solberg T. X-ray photother-apy for canine brain masses. Radiat Oncol Investig. 1997; 5 (1): 8-14.

6. Miladi I, Alric C, Dufort S, et al. The In Vivo Radiosensitizing Effect of Gold Nanoparticles Based MRI Contrast Agents. Small. 2014; 10 (6): 1116-24.

7. Le Duc G, Miladi I, Alric C, et al. Toward an Image-Guided Microbeam Radiation Therapy Using Gadolinium-Based Nanoparticles. ACS Nano. 2011; 5 (12): 9566-74.

8. Hainfeld JF, Dilmanian FA, Zhong Z, Slatkin DN, Kalef-Ezra JA, Smilowitz HM. Gold nano-particles enhance the radiation therapy of a murine squamous cell carcinoma. Phys Med Biol. 2010; 55 (11): 3045-59.

9. Hainfeld JF, Slatkin DN, Smilowitz HM. The use of gold nanoparticles to enhance radiothera-py in mice. Phys Med Biol. 2004; 49 (18): 309-15.

10. Hainfeld JF, Smilowitz HM, O'Connor MJ, Dilmanian FA, Slatkin DN. Gold nanoparticle imaging and radiotherapy of brain tumors in mice. Nanomedicine. 2013; 8 (10): 1601-09.

11. Dufort S, Le Duc G, Salomé M, et al. The High Radiosensitizing Efficiency of a Trace of Gadolinium-Based Nanoparticles in Tumors. Sci Rep. 2016; 6 (June): 1-8.

12. Komatsu T, Nakamura K, Okumura Y, Konishi K. Optimal method of gold nanoparticle ad-ministration in melanoma bearing mice. Exp Ther Med. 2018 Jan 12; 15 (3): 2994-9.

13. Rousseau J, Boudou C, Estève F, Elleaume H. ConvectionEnhanced Delivery of an lodine Tracer Into Rat Brain for Synchrotron Stereotactic Radiotherapy. Int J Radiat Oncol. 2007 Jul; 68 (3): 943-51.

14. Mello RS, Callisen H, Winter J, Kagan a R, Norman A. Radiation dose enhancement in tu-mors with iodine. Med Phys [Internet]. 1983 Jan; 10 (1): 75-8.

15. Липенгольц А. А., Черепанов А. А., Кулаков В. Н., Григорьева Е. Ю., Меркулова И. Б., Шейно И. Н. Сравнение противоопухолевой эффективности висмута и гадолиния как дозоповышающих агентов в препаратах для фотонзахватной терапии. Химико-фармацевтический журнал. 2017; 51 (9): 34-7.
16. Черепанов А. А., Липенгольц А. А., Насонова Т. А., Добрынина О. А., Кулаков В. Н., Шейно И. Н., и др. Увеличение противоопухолевого эфффекта рентгеновского облучения при помощи гадолиний-содержащего препарата на примере мышей с трансплантированной меланомой B16F10. Медицинская физика. 2014; (3): 66-9.

17. Maggiorella L, Barouch G, Devaux C, Pottier A, Deutsch E, Bourhis $\mathrm{J}$, et al. Nanoscale radio-therapy with hafnium oxide nanoparticles. Futur Oncol. 2012; 8 (9): 1167-81.

18. Bonvalot S, Le Pechoux C, De Baere T, Kantor G, Buy X, Stoeckle $E$, et al. First-in-Human Study Testing a New Radioenhancer Using Nanoparticles (NBTXR3) Activated by Radiation Therapy in Patients with Locally Advanced Soft Tissue Sarcomas. Clin Cancer Res. 2017 Feb 15; 23 (4): 908-17.

19. Hainfeld JF, O'Connor MJ, Dilmanian FA, Slatkin DN, Adams DJ, Smilowitz HM. Micro-CT enables microlocalisation and quantification of Her2-targeted gold nanoparticles within tu-mour regions. Br J Radiol. 2011; 84 (1002): 526-33. DOl:10.1259/ bjr/42612922.

20. Le Duc G, Corde S, Charvet A-M, Elleaume H, Farion R, Le Bas J-F, et al. In Vivo Meas-urement of Gadolinium Concentration in a Rat Glioma Model by Monochromatic Quantitative Computed Tomography. Invest Radiol. 2004 Jul; 39 (7): 385-93

21. Липенгольц А. А., Будаева Ю. А., Блайкнер М., Черепанов А. А., Меньков М. А., Кулаков В. Н., и др. Количественное определение йода при помощи рентгеновской компьютерной томографии для дозиметрического обеспечения фотонзахватной терапии. Вестник РГМУ. 2016; (6): 16-20.

22. Pervova W, Lipengolts AA, Cherepanov AA, Abakumov MA. Study of iodine, gadolinium and bismuth quantification possibility with micro-CT IVIS spectrumct in vivo imaging system. J Phys Conf Ser. 2017; 784 (1): 12043.

23. Воробьева Е. С., Липенгольц А. А., Черепанов А. А., Григорьева Е. Ю., Нечкина И. Н., Калыгина Н. С., и др. Возможность проведения фотон-захватной терапии с использованием 6 МВ фотонного излучения. Вестник РГМУ. 2017; (4): 63-7.

24. Черепанов А. А., Липенгольц А. А., Воробьева Е. С., Кулаков В. Н., Климанов В. А., Григорьева Е. Ю. Исследование увеличения энерговыделения в среде за счет присутствия тяжелого элемента с использованием дозиметра Фрике. Медицинская физика. 2016; 72 (4): 38-41.

25. Bristow RG, Hill RP. Comparison between in vitro radiosensitivity and in vivo radioresponse in murine tumor cell lines II: in vivo radioresponse following fractionated treatment and in vitro/in vivo correlations. Int J Radiat Oncol. 1990 Feb; 18 (2): 331-45.

26. Le UM, Kaurin DGL, Sloat BR, Yanasarn N, Cui Z. Localized irradiation of tumors prior to synthetic dsRNA therapy enhanced the resultant anti-tumor activity. Radiother Oncol. 2009 Feb; 90 (2): 273-9. 